\title{
Option to apply personal deductions to decrease the taxable base or increase the tax recovery of individuals in Mexico
}

\section{Opción de aplicar deducciones personales para disminuir la base gravable o incrementar la recuperación de impuestos de personas físicas en México}

\author{
HERNANDEZ-SANDOVAL, Rosa Hilda*†, NAHUAT-ARREGUIN, Juan Jesús, SUAREZ \\ RODRIGUEZ-Glenda Lila and TORRES-HERNANDEZ, Eric Arturo
}

Universidad Autónoma de Coahuila, Blvd. V Carranza S/N Col. Republica, CP25280, Saltillo, Coah., México.

ID $1^{\text {st }}$ Author: Rosa Hilda, Hernandez-Sandoval / ORC ID: 0000-0002-0563-5705, Researcher ID Thomson: X-3965-2018, CVU CONACYT ID: 640368

ID $1^{\text {st }}$ Coauthor: Juan Jesús, Nahuat-Arreguin / ORC ID: 0000-0001-8371-4313, Researcher ID Thomson: X-7934-2018, CVU CONACYT ID: 260350

ID $2^{\text {nd }}$ Coauthor: Glenda Lila, Suarez-Rodriguez / ORC ID: 0000-0001-5397-0340, Researcher ID Thomson: X-7932-2018, CVU CONACYT ID: 953743

ID $3^{\text {rd }}$ Coauthor: Eric Arturo, Torres-Hernandez / ORC ID: 0000-0002-3264-2986, Researcher ID Thomson: X-7921-2018, CVU CONACYT ID: 953736

DOI: $10.35429 / J L E .2019 .4 .3 .29 .37$

Received February 15, 2019; Accepted June 25, 2019

\begin{abstract}
The objective of this research is to identify all personal deductions of the 151 article of the income tax law that meet all the fiscal requirements, so that individuals can deduct when presenting their annual income tax return. Personal deductions are the concepts that the legislator allows to deduct form the annual income tax statement. When to discount personal deductions? The process is performed when the taxpayer applies certain deductions established by law. Taxpayer must know specific aspects such as: deduction's types, that these deductions are strictly necessary, the limitations that the legislator allows to deduct, as well as who can be the beneficiaries of the taxpayer, among other requirements. The individuals may enjoy the benefits by subtracting the accumulative income. For the practical case are used: the ISR law, Regulations, RMF and decrees. If the taxpayer makes use of this option in a legal manner, the taxpayer will have as a result paying less taxes or to increase the balance at their favor and therefore may request the tax refund.
\end{abstract}

Personal deductions, Taxes, Benefits

\begin{abstract}
Resumen
El objetivo de esta investigación es identificar todas las deducciones personales que se encuentran en el artículo 151 de la ley de Impuesto sobre la Renta y que éstas a la vez reúnan todos y cada unos de los requisitos fiscales para que el contribuyente persona física pueda deducir al presentar la declaración anual. Deducciones personales son los conceptos que el legislador permite descontar en su declaracion anual. Cuando descontar las deducciones personales?. El proceso se realiza cuando el contribuyente al erogar determinadas deducciones que establece la ley, debe conocer ciertos aspectos como: el tipo de deducción, que éstas sean estrictamente necesarias, conocer las limitantes que el legislador permite deducir, así como quienes pueden ser los beneficiarios del contribuyente, entre otros requisitos. Las personas físicas podrán gozar de los beneficios que permite el legislador al restar del ingreso acumulable. Para el caso práctico se utiliza la Ley de ISR, Reglamentos, RMF y Decretos. Si el contribuyente hace uso de esta opcion de forma legal, el contribuyente tendra como resultado pagar menos impuestos o bien incrementar el saldo a favor de impuesto sobre la renta y por ende podrá solicitar la devolución del impuesto.
\end{abstract}

Deducciones personales, Impuestos, Beneficios

Citation: HERNANDEZ-SANDOVAL, Rosa Hilda, NAHUAT-ARREGUIN, Juan Jesús, SUAREZ RODRIGUEZ-Glenda Lila and TORRES-HERNANDEZ, Eric Arturo. Option to apply personal deductions to decrease the taxable base or increase the tax recovery of individuals in Mexico. Journal-Law and Economy. 2019. 3-4: 29-37.

\footnotetext{
* Correspondence to Author (email: rosahildahdz@prodigy.net.mx)

$\dagger$ Researcher contributing as first author.
} 


\section{Introduction}

This investigation was conducted in 2019, in the city of Monclova, Coahuila, Mexico. The objective of this research is to identify all the personal deductions found in article 151 of the Income Tax Law and that these meet all the fiscal requirements so that the individual taxpayer can deduct them when presenting the annual return.

Personal deductions are the concepts that legislators allow to be deducted in their annual declaration. In the methodology for the practical case, we use the Income Tax Law (ISR), Income Tax Regulations, Miscellaneous Fiscal Resolution, Decrees and Jurisprudence, among others. This investigation is of a descriptive type to identify the requirements for personal deductions.

\section{Justification}

This research will benefit taxpayers who receive income from salaries, business, professional activity, rent, interest, among others. It is a relevant and applicable subject, and it will provide knowledge for people who choose to apply personal deductions with the requirements established by law, so that they can solve a specific issue, because they will have tax arguments.

General deductions, or personal deductions, are considered optional, that is to say, not mandatory for the governed, it is a benefit for the taxpayers that wish to diminish the taxable base or increase their balance in favor of ISR in their annual declaration.

\section{Problem}

Taxpayers are unaware of the concepts that legislators allow to be discounted from the annual return, together with the countless requirements that each of the tax vouchers must contain; because of this situation, the vouchers or balances return are rejected in favor of the annual return.

\section{Hypothesis}

H1. If individual taxpayers deduct from their annual return the receipts with the tax requirements, they will be able to receive a balance in favor of income tax, or pay less taxes.
Ho. If taxpayers do not apply the required personal deductions, they will not be able to receive the benefits offered by the legislators in their return.

\section{Objectives}

A general objective and two specific objectives are presented to determine the line of work.

\section{General Objective}

To identify all the personal deductions found in article 151 of the Income Tax Law and that these meet each and every one of the tax requirements, so that the taxpayer can deduct them in their annual return.

\section{Specific objectives}

- To identify the personal deductions found in Article 151 of the Income Tax Law

- To describe the tax requirements for personal deductions

\section{Theoretical Framework}

\section{Background.}

In accordance with the Political Constitution of the United Mexican States, Article 31, Section IV, establishes the obligation to contribute to public spending in a proportional and equitable manner. "Mexicans are obliged to contribute to public spending, both for the Federation and the Federal District or the State and Municipality in which they reside, in a proportional and equitable manner as declared by law" (CPEUM, 2019).

\section{Income Tax Law.}

In accordance with Article 151 of the Income Tax Law (LISR), natural persons resident in the country who obtain income from those indicated in this Title, in order to calculate their annual tax, must make, in addition to the deductions authorized in each Chapter of this Law that correspond to them, the following personal deductions (Calvo \& Montes, 2018). 


\section{Section I. Fees}

Payments for medical and dental fees, as well as hospital expenses, made by the taxpayer for himself, for his spouse or for the person with whom he lives in a common-law relationship and for his ascendants or descendants in a straight line, provided that such persons do not receive during the calendar year income in an amount equal to or greater than that resulting from the calculation of the general minimum wage in the taxpayer's geographical area raised per year, and made by means of the taxpayer's nominative check, electronic transfer of funds, from accounts opened in the name of the taxpayer in institutions that make up the financial system and the entities that the Bank of Mexico authorizes for such purpose or by means of credit, debit or service cards.

The tax authorities may release from the obligation to pay disbursements through the means established in the previous paragraph, when these are made in towns or rural areas without financial services.

When analyzing the fraction of fees that mentions who can be the beneficiaries of the taxpayer, the limitation of income to obtain the benefit, the disjunctive of deducting expenses of the spouse or concubine, without limitation in ascendants and descendants in a straight line with the restriction that they do not receive a high minimum wage per year, although it should be considered UMAS instead of minimum wages as established by LISR.

\section{Strictly indispensable.}

Also deductible are payments made for medical, dental or nursing fees, for analyses, clinical studies or prostheses, hospital expenses, purchase or rental of devices for the establishment or rehabilitation of the patient, derived from the disabilities referred to in article 477 of the Federal Labor Law, which establishes: when the risks are realized, temporary, partial permanent, total permanent disability, death and disappearance derived from a criminal act (Trueba, 2014).
When there is a certificate or proof of disability issued by the public institutions of the National Health System, or those deriving from a disability in terms of the provisions of the General Law for the Inclusion of Persons with Disabilities and there is a certificate of recognition and qualification of disability issued by the aforementioned public institutions in accordance with the latter law. The provisions of this paragraph shall not be subject to the limit established in the last paragraph of this article.

\section{Deductible medicine billed by hospital.}

For the purposes of article 151, section I, of the Act, the deductions referred to in that section shall include the strictly essential costs incurred for the purchase or rental of equipment for the restoration or rehabilitation of the patient, medicines included in the documents issued by hospital institutions, fees for nurses and for analyses, clinical studies or prostheses (ISR, 2019).

Limiting optical lenses.

Likewise, the expenses incurred for the purchase of graduated optical lenses to correct visual defects are included in the deductions referred to in the previous paragraph, up to an amount of $\$ 2,500.00 \mathrm{MXN}$, in the fiscal year, for each one of the persons to which the mentioned fraction refers, provided that the characteristics of such lenses are described in the tax receipt or, in its absence, the diagnosis of an ophthalmologist or optometrist is available (RISR, 2019).

In the case of temporary incapacity or partial permanent incapacity, or disability, the deduction referred to in the previous paragraph will only be applicable when said incapacity or disability is equal to or greater than $50 \%$ of normal capacity.

For the purposes of the deduction referred to in the second paragraph of this section, the corresponding digital tax receipt must contain the specification that the expenses covered by it are directly related to the care of the incapacity or disability in question. Additionally, the Tax Administration Service (SAT), by means of general rules, may establish other requirements that the digital tax receipt via Internet must contain. 
RMF 3.17.11. Payments for dental fees include those made to stomatologists under the terms of Official Mexican Standard "NOM-013SSA2-2006. For the prevention and control of oral diseases", such as the Medical Dentist, Dental Surgeon, Licensed Stomatologist, Licensed Dental Surgeon, Military Dental Surgeon and any other licensed oral health professional, when the provision of services requires a medical degree (RMF, 2018).

\section{Fraction II. Funeral expenses}

Funeral expenses in the part not exceeding the general minimum wage of the geographical area of the taxpayer raised per year, made for the persons indicated in the fraction above (Calvo \& Montes, 2018).

ISR Art. 266 For effects of article 151, fraction II of the Law, in the cases of expenditures to cover future funerals, these will be deductible until the calendar year in which the respective funeral services are used (ISR, 2019).

\section{Section III Donations}

Donations that are neither onerous nor remunerative, that satisfy the requirements set forth in this Law and in the general rules established for this purpose by the Tax Administration Service, and which are granted in the following cases:

a). To the Federation, the states or municipalities, their decentralized agencies that pay taxes in accordance with Title III of this Law, as well as international agencies of which Mexico is a full member, provided that the purposes for which they were created correspond to the activities for which authorization may be obtained to receive tax-deductible donations. Donations. Article 249 of the ISHR states that donations that are not onerous or remunerative and are made to human rights institutions that have the status of autonomous public bodies, and are taxed, are considered deductible (ISHR, 2019).

b). To the entities referred to in the sixth paragraph of article 82 of this Law.

c). To the entities referred to in articles 79, section XIX and 82 of this Act. d). To the legal entities referred to in Article 79, sections VI, X, XI, XX and XXV of this Law and which comply with the requirements established in Article 82 of this Law.

e). To the associations and civil societies that grant scholarships and comply with the requirements of Article 83 of this Law.

\section{f). To business school programs.}

The Tax Administration Service shall publish in the Official Gazette of the Federation and shall publish in its Internet web page the data of the institutions referred to in paragraphs b), c), d) and e) of this fraction that meet the aforementioned requirements. In the case of donations to educational institutions, they will be deductible provided that they are public establishments or those owned by individuals who have authorization or recognition of official validity of studies under the terms of the General Education Act, and are intended for the acquisition of investment goods, scientific research or development of technology, as well as administrative expenses up to the amount, in the latter case, indicated in the Regulations of this Act; they are not onerous or remunerative donations, in accordance with the general rules determined for such purpose by the Ministry of Public Education, and such institutions have not distributed any surplus to their partners or members during the last five years (Calvo \& Montes, 2018).

Limitation of donations.

The total amount of the donations referred to in this fraction shall be deductible up to an amount not exceeding $7 \%$ of the cumulative income that serves as the basis for calculating the income tax payable by the taxpayer in the fiscal year immediately preceding that in which the deduction is made, before applying the deductions referred to in this article. When donations are made in favor of the Federation, the states, the municipalities, or their decentralized agencies, the deductible amount may not exceed $4 \%$ of the cumulative income referred to in this paragraph, without in any case the limit of the deduction in the case of these donations, and those made to different authorized donors, exceeding the 7\% mentioned (Calvo \& Montes, 2018). 


\begin{tabular}{|l|l|}
\hline \multicolumn{1}{|c|}{ Concept } & Value \\
\hline $\begin{array}{l}\text { Accumulated income from the } \\
\text { previous year 2017. }\end{array}$ & $\$ 1000,000$. \\
\hline (x) Limiting 7\% of LISR & $70,000$. \\
\hline $\begin{array}{l}\text { Up to \$70,000.00 may be deducted } \\
\text { for 2018, with the requirements of } \\
\text { the CFDI tax receipt }\end{array}$ \\
\hline
\end{tabular}

Table 1 The table shows the limitation of the donation that can be deducted by the taxpayer in the following year according to the data of the return

Income can be accumulated between related parties.

When donations are made between related parties, the donor cannot contract with the related party that made the donation, the provision of services, the sale, or the granting of the temporary use or enjoyment of goods. Otherwise, the donor must consider the amount of the deduction made for the corresponding donation as a cumulative income for income tax purposes, updated from the date on which the deduction was applied and until the moment in which it is accumulated (Calvo \& Montes, 2018).

\section{Cash deductible paid in rural areas.}

For the purposes of Article 27, section III, third paragraph of the Act, the tax authorities shall decide on applications for authorization to release the obligation to pay outlays by the means indicated in the first paragraph of that section, in accordance with the following: I. The circumstances of each case will be assessed considering, among others, the following parameters: a) That payments made to suppliers are made in towns or rural areas, without financial services (ISR, 2019).

\section{Fraction IV Interest.}

The real interest effectively paid during the period for mortgage loans destined to the acquisition of their home contracted with the institutions that make up the financial system, provided that the total amount of the loans granted for said property does not exceed seven hundred and fifty thousand investment units.
For these purposes, real interest shall be considered to be the amount in which interest effectively paid in the period exceeds the annual adjustment for inflation of the same period and shall be determined by applying the provisions of the third paragraph of Article 134 of this Law, for the corresponding period (Calvo \& Montes, 2018). In addition, the taxpayer must have the tax receipt for the deduction.

\begin{tabular}{|l|l|l} 
Deductibles & UDIS value Deductible value
\end{tabular}

\begin{tabular}{|l|l|l}
\hline 650,000 & 6.2590 & $\$ 4,068,350.00$
\end{tabular}

Table 2 Limitation of the credit so that the originated interests are deductible by the taxpayer according to UDIS

Deductible real interest. Interest. In accordance with ISR Art. 250, for the purposes of Article 151, Section IV of the Law, the amount of actual interest paid in the year in question, including arrears, corresponding to mortgage loans, shall be deductible; the interest that may be deducted shall be the one paid in the year in which the deduction is made (ISR, 2019).

Withdrawal of IMSS contributions and income. The interest referred to in article 151, section IV of the Law shall also be deductible when the payment thereof is made using the amount of the withdrawals of the contributions and their income, from the housing sub-account of the individual account provided for in the Social Security Law, of the housing fund subaccount of the individual account of the Retirement Savings System provided for in the Law on the Institute of Social Security and Services for State Workers, as well as the housing fund for active members of the armed forces provided for in the Law on the Institute of Social Security for the Mexican Armed Forces.

\section{Section V Supplementary contributions}

Supplementary retirement contributions made directly to the supplementary retirement contributions sub-account, under the terms of the Law on Retirement Savings Systems or to personal retirement plan accounts, as well as voluntary contributions made to the voluntary contributions sub-account, provided that in the latter case such contributions comply with the permanence requirements established for retirement plans pursuant to the second paragraph of this section (Calvo \& Montes, 2018). 
Limitation of personal deductions.

The amount of the deduction to which this fraction refers will be up to $15 \%$ of the taxpayer's cumulative income in the year, without such contributions exceeding the equivalent of five general minimum salaries in the taxpayer's geographic area per year (Calvo \& Montes, 2018).

\begin{tabular}{|l|c|}
\hline \multicolumn{1}{|c|}{ Concept } & \multicolumn{1}{c|}{ Limitation } \\
\hline (80.60)(365)(5) UMA & $\$ 147,095.00$ \\
\hline $\begin{array}{l}\text { If the taxpayer receives total } \\
\text { income of } \$ 1000.0000 .00 \text { for } \\
15 \%\end{array}$ & $\$ 150,000.00$ \\
\hline $\begin{array}{l}\text { Both values are compared } \\
\text { and the lower value is } \\
\text { deducted, in this case the first } \\
\text { one }\end{array}$ & $\$ 147,095.00$ \\
\hline
\end{tabular}

Table 3 Comparison to identify the limitation of the annual value of the personal deduction of a taxpayer who receives $\$ 1000,000.00$, and compare to identify the one that is less, in that case applies 5 UMAS

\section{Personal, non-structural deductions.}

The Supreme Court of Justice of the Nation (SCJN) has classified as non-structural those expenditures that are not linked to the production or obtaining of the object of the tax; since they have no relation to the generation of the profit, they did not influence the obtaining of the income. These types of deductions are the result of a positive sanction provided by a typically promotional rule called fiscal expenses originated by a tax reduction. They are disbursements made for personal consumption, whether because of their origin, purpose or effect they are contingent expenses, and have no incidence on obtaining tax revenues (SCJN, 2017).

\section{Limitation of the lesser.}

According to the SCJN, the limitation of personal deductions does not generate a regressive tax. The regulatory portion mentioned above establishes as the upper limit for the amount of personal deductions that may be applied, the lower amount between (a) the one corresponding to 4 , now 5 , minimum wages that must be high UMAS per year and (b) the one equivalent to $10 \%$, now $15 \%$, of the total income of the taxpayer as mentioned in table 3 and 4 (SCJN, Thesis, 2017).
Personal retirement plans are those accounts or investment channels that are established with the sole purpose of receiving and managing resources destined exclusively to be used when the holder reaches the age of 65 or in cases of disability or incapacity of the holder to carry out personal paid work in accordance with the law, provided they are managed in individualized accounts by insurance institutions, credit institutions, stockbrokers, retirement fund managers or investment company operators authorized to operate in the country, and provided they obtain prior authorization from the SAT (Calvo \& Montes, 2018).

When the resources invested in the subaccounts of complementary retirement contributions, in the sub-accounts of voluntary contributions or in the personal retirement plans, as well as the yields they generate, are withdrawn before the requirements established in this fraction are fulfilled, the withdrawal will be considered accumulative income in the terms of Chapter IX of this Title.

In the event of the death of the holder of the personal retirement plan, the designated beneficiary or the heir shall be obliged to accumulate the withdrawals made from the account or investment channels, as the case may be, with other income of the fiscal year.

\section{Section VI. Insurance premiums}

Premiums for insurance of medical expenses, complementary or independent of health services provided by public social security institutions, provided that the beneficiary is the taxpayer himself, his spouse or the person with whom he lives in a common-law relationship, or his ascendants or descendants, in a straight line.

RISR 268 For the purposes of Article 151, Section VI of the Law, premiums paid for health insurance are considered deductible, provided that the preventive part covers only the payments and expenses referred to in Article 151, Section I of the Law and Article 264 of these Regulations (RISR, 2019). 


\section{School transport}

Expenses for school transportation of descendants in a straight line when it is mandatory under the legal provisions of the area where the school is located or when for all students such expenses are included in the tuition. For these purposes, the receipt must include the amount corresponding to school transportation and be made by means of a check made out to the taxpayer, electronic fund transfers from accounts opened in the name of the taxpayer in institutions that make up the financial system and the entities authorized by the Bank of Mexico or by means of credit, debit or service cards. When they are in rural areas, they may be deducted even if they are paid by means other than those established.

Transport when required.

For the purposes of Article 151, Section VII of the Act, the requirement set out in that section shall be deemed to be met when the school concerned requires all its pupils to pay for the school transport service. Schools in this situation must prove that they have allocated the corresponding revenue to the provision of transport service (RISR, 2019).

\section{Local taxes on salary income}

Payments made for local income tax on salaries and in general for the provision of a subordinate personal service, provided that the rate of such tax does not exceed 5\%. To determine the geographical area of the taxpayer, the place where his or her home is located at December 31 of the year in question shall be considered. Those persons who, as of that date, have their domicile outside the national territory will be attended to in the geographical area corresponding to the Federal District. It is important not to confuse this tax with the Payroll Tax, this tax is local.

\begin{tabular}{|c|c|}
\hline Concept & Value \\
\hline $\begin{array}{l}\text { Total annual income received by } \\
\text { the worker }\end{array}$ & $\$ 500.000 .0$ \\
\hline 1). $15 \%$ of total income & $\$ 75.000 .0$ \\
\hline 2). Daily UMA $\$ 80.60$ & $\$ 147,095.0$ \\
\hline
\end{tabular}

Table 4 Personal deductions that can be made by the worker according to income and the comparative that is lower, in this case $15 \%$ of the salary that was lower
To make use of the benefit the person must have the tax receipt with the tax requirements, which must be issued by private educational institutions, which can be deducted in the annual return. Tuition payments are from pre-school to high school level or equivalent according to the limitations mentioned at the time of application (FEDERATION \& DOF, 2018).

\begin{tabular}{|l|r|}
\multicolumn{1}{|c|}{ Educational level } & Deduction limit \\
\hline Preschool & $\$ 14,200.00$ \\
\hline Primary & $\$ 12,900.00$ \\
\hline Secondary & $\$ 19,900.00$ \\
\hline Technical Professional & $\$ 17,100.00$ \\
\hline Technical High School & $\$ 24,500.00$ \\
\hline
\end{tabular}

Table 5 Tax incentive for the payment of educational services or tuition fees, according to the decree on tax benefits to be deducted in the annual return

The SAT makes available a list of educational institutions with a database that in 2018 issued vouchers with CFD, or CFDI, tax requirements (www.sat.gob.mx, 2019). The school must be authorized or recognized as officially valid under the terms of the General Education Law, and the receipt must contain the full name, CURP, and educational level of the student. The amount and concept of the services exclusively for education must be separate.

The following are not deductible: registration, maintenance, educational material, school transport, additional subjects or courses, uniforms or exams of any kind. In addition to the above requirements, payment must be made by check to the taxpayer, transfer of accounts in credit institutions, credit card, debit card or service card (FEDERATION \& DOF, 2018).

\section{Case study to compare}

A practical case is presented for comparison when a taxpayer chooses to apply the personal deductions according to table No. 6, and another taxpayer who chooses not to consider according to table 7, to observe the effects. In the first table, the taxpayer will pay less taxes than the second one when comparing the income tax produced by both, which is reflected in table 8 .

Fiscal Stimulus Decree D.O.F. 2013. 


\begin{tabular}{|l|l|r|}
\hline \multicolumn{2}{|c|}{ Concept } & \multicolumn{1}{c|}{ Value } \\
\hline & Taxed income & $\$ 480,000$. \\
\hline- & Personal deductions & $\$ 64,100$. \\
\hline$=$ & Taxable base & $\$ 415,900$. \\
\hline $\mathrm{X}$ & Tariff art.152 LISR & \\
\hline$=$ & Income tax payable for the year & $\$ 76,020$. \\
\hline
\end{tabular}

Table 6 The taxpayer opted to apply personal deductions to reduce the taxable base, compare with table 7

\begin{tabular}{|l|l|r|}
\hline \multicolumn{2}{|c|}{ Concept } & \multicolumn{1}{|c|}{ Value } \\
\hline- & Taxed income & $\$ 480,000$. \\
\hline$=$ & Personal deductions & 0 \\
\hline & Taxable base & $\$ 480,000$. \\
\hline$=$ & Tariff art.152 LISR & \\
\hline
\end{tabular}

Table 7 The taxpayer chose not to project personal deductions and the taxable base was higher when comparing table 6

\begin{tabular}{|c|c|c|}
\hline $\begin{array}{c}\text { ISR due } \\
\text { considering } \\
\begin{array}{c}\text { Personal } \\
\text { Deductions to } \\
\text { worker }\end{array}\end{array}$ & $\begin{array}{c}\text { ISR due } \\
\text { without } \\
\text { considering } \\
\text { Personal } \\
\text { Deductions }\end{array}$ & $\begin{array}{c}\text { Difference or } \\
\text { benefit when } \\
\text { applying the } \\
\text { deductions }\end{array}$ \\
\hline$\$ 76,020$. & $\$ 92,513$. & $\$ 16,493$. \\
\hline
\end{tabular}

Table 8 Comparison when the taxpayer applies or not the personal deductions, it is a benefit of $\$ 16,493.00$ when applying personal deductions

\section{Research Methodology}

We analyzed the types of personal deductions found in Article 151 of the Income Tax Law, as well as the requirements of the deductions, adding practical cases to improve understanding, determination of limitation of deductions according to analysis and legal argumentation.

The procedures present a practical case to compare the effect: when the taxpayers choose to apply personal deductions and when they choose not to apply them, as well as the effect of the first option. In this process, legal, juridical and constitutional arguments were applied, such as: income tax, income tax regulations, Miscellaneous Resolution, decrees, jurisprudence and the Political Constitution of the United Mexican States.

\section{Type of Investigation}

This investigation is of a descriptive type, considering each of the personal deductions established by law, as well as the requirements that each deduction must contain applying the tax provisions according to the legislation.
A qualitative approach is applied since documentary information was taken, as well as information from Fiscal, Legal, Constitutional and Political laws of the United Mexican States, Fiscal Miscellaneous Resolution, Official Gazette of the Federation and Jurisprudence.

\section{Results}

According to Table 6 and Table 7, a comparison is presented in which Table 6 opted to apply personal deductions, while Table 7 opted not to apply them. The result is that the more deductions with requirements and limitations that the taxpayer considers, the less income tax is payable or the more the balance is in favor, in this case, with the deductions, the income tax would be in favor, therefore it is a benefit that all taxpayers can apply in their annual return.

\section{Conclusions}

Taxpayers can plan during the fiscal year the personal deductions that can be made or applied in the annual return, additionally they can request advice from the authority or a tax expert because the taxpayers do not apply the personal deductions due to ignorance, together with multiple requirements that sometimes they do not know; additionally, taxpayers do not request the voucher at the time or do not pay with the legal means to be able to deduct without contingencies in the annual return, and therefore receive the benefits.

The collection administration, the SAT, should be more efficient in the return of taxes, and when it makes adjustments or decreases the balance in favor, this should be founded and motivated, it should be expressed with precision, the normative hypothesis configured, that the authority legally informs the taxpayer of the cause of the rejection or decrease of the ISR. The taxpayer must verify that there are two different types of deductions in the annual return, one of which is the one permitted by the legislation under Article 151 of the Income Tax Law, which applies $15 \%$ deduction from the taxpayer's total income or five UMAS per year, and compare the lower of the two. While the other is for the stimulus of the Decree, that is to say, the fees, these are of a different nature, in other words, considering this point, the taxpayer will have the opportunity to raise the limit of personal deductions. 


\section{References}

Calvo , E., \& Montes, E. (2018, 01 31). Ley de Impuesto sobre la renta. editorial themis, S.A. $D E$ C.V. MEXICO, MEXICO, CIUDAD: THEMIS.

CPEUM. (2019). CPEUM. CONSTITUCION POLITICA DE LOS ESTADOS UNIDOS MEXICANOS .

FEDERACION, D. O., \& DOF, 2. (2018, diciembre 26). Estimulo Fiscal 2013. 2013 . CD MEXICO, MEXICO, MEXICO.

RISR. (2019, 01 01). REGLAMENTO DE IMPUESTO SOBRE LA RENTA. THEMIS . RMF. (2018, 12 22). WWW.GOB.MX. (D. O. FEDERACION, Producer) Retrieved 07 18, 2019, from hhtt//WWW.GOB.MX: WWW.GOB.MX

SCJN. (2017, 10 01). Juris ded.persn. Retrieved 08 15, 2019, from SCJN: IUS

SCJN. (2017, 10 01). Juris deducciones.person. (G. D. FEDERACION, Ed.) Retrieved 08 18, 2019, from SCJN : IUS

Trueba, A. (2014, 07 31). Ley Federal de Trabajo. Derechos humanos laborales , 938. (PORRUA2014, Ed.)

www.diputados.gob.mx. (2015, 12 06). Mexico: Camara de Diputados.

www.diputados.gob.mx. (2019, 06 01). (978607-614-467-14-218-9) . (Tehmis, Ed.) Mexico: Fiscal.

www.sat.gob.mx. (2019, 08 01). SAT. Retrieved from SAT. 